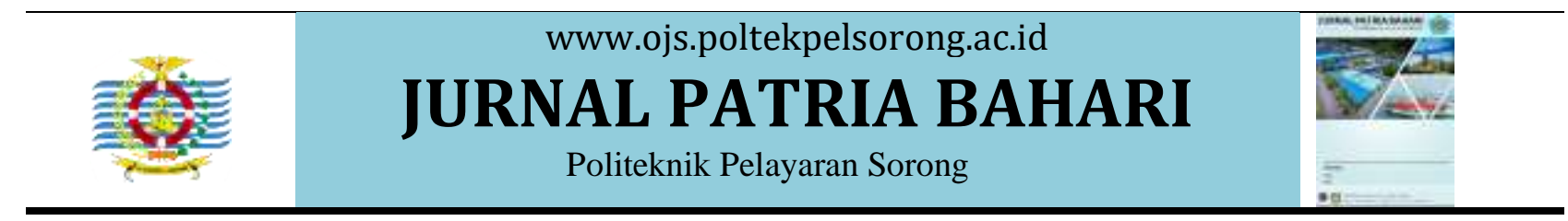

Jurnal PATRIA BAHARI

Vol. 1, No. 2, November 2021

pISSN: 2776-5881

Hal 35-45

eISSN: 2798-0510

\title{
PEMBENTUKAN KARAKTER KEPEMIMPINAN PANCASILA DI POLITEKNIK PELAYARAN SORONG (Suatu Telaah Pada Mata Kuliah Pendidikan Pancasila)
}

\author{
Gigieh Cahya Permady ${ }^{1}$, Gilang Zulfikar ${ }^{2}$, Agus Sulistiono ${ }^{3}$, Bernard Ferdinan \\ Nugroho Laim ${ }^{4}$ \\ Politeknik Pelayaran Sorong ${ }^{1}$, Universitas Pamulang ${ }^{2}$, Politeknik Pelayaran Sorong ${ }^{3}$, \\ Politeknik Pelayaran Sorong ${ }^{4}$
}

\begin{abstract}
Abstrak
Pentingnya pembentukan karakter Pancasila di perguruan tinggi. Fokus penelitian ini mengenai tentang mata kuliah Pendidikan Pancasila sebagai salah satu upaya dalam pembentukan karakter kepemimpinan Pancasila pada mahasiswa di Politeknik Pelayaran Sorong. Pentingnya karakter kepemimpinan pancasila ditanamkan kepada mahasiswa agar nilai-nilai Pancasila menjadi barometer kepemimpinan ideal bagi mereka yang kelak akan menjadi seorang pemimpin di bidang profesinya masing-masing. Penelitian ini menggunakan pendekatan kualitatif dengan sumber data maupun hasil penelitian dalam bentuk kepustakaan (library research) berupa deskripsi kata-kata. Adapun objek dalam penelitian ini adalah perangkat pembelajaran mata kuliah Pendidikan Pancasila seperti RPS dan buku ajar. Hasil penelitian mengungkapkan pembentukan karakter kepemimpinan Pancasila dalam matakuliah Pendidikan Pancasila dapat ditinjau dari RPSnya terlihat capaian pembelajaran matakuliah pendidikan Pancasila menekankan mahasiswa memiliki sifat religius, kemanusiaan, cinta tanah air, serta mampu bertanggungjawab atas pencapaian hasil kerja kelompok dan melakukan supervisi dan evaluasi terhadap penyelesaian pekerjaan yang ditugaskan kepada pekerja yang berada di bawah tanggungjawabnya. Didukung buku ajar dan metode small group discussion dan studi kasus dengan keuntungan mahasiswa tidak hanya memperoleh pengetahuan dan keterampilan yang berkaitan dengan bidang keahliannya saja, tetapi juga berkembang keterampilan komunikasi, inisiatif, bekerja dalam kelompok, berbagi informasi, dan penghargaan terhadap orang lain adalah nilai-nilai karakter kepemimpinan Pancasila yang ideal bagi mahasiswa.
\end{abstract}

Kata Kunci: Karakter, Kepemimpinan Pancasila, Pendidikan Pancasila

\section{PENDAHULUAN}

Generasi muda Indonesia merupakan aset bangsa harus dibina dan diarahkan agar mampu menjadi elemen unggul di masyarakat yang mampu menciptakan sebuah kemajuan bangsa di masa depan. Karena para pendiri bangsa memiliki kepercayaan bahwa generasi muda saat ini sanggup merubah nasib masa depan bangsa yang berdiri sejajar dengan bangsa lainnya. Generasi muda merupakan bagian integral dari proses pembangunan 
nasional. Dengan kata lain, pembangunan tidak hanya melekat dengan ekonomi dan sosial, tetapi generasi mudanya juga menjadi suatu hal penting dalam pembangunan nasional (Affandi, 2011). Dengan demikian, diperlukannya wahana dan sarana dalam pengembangan diri generasi muda sebagai pembinaan karakter bangsa yang siap menyongsong masa depan. Generasi muda yang mumpuni dalam hal kapasitas dan psikis yang dianggap mampu menerima pembinaan karakter dan mengembangkannya yakni mahasiswa.

Mahasiswa memiliki karakteristik yang berbeda dengan status warganegara lainnya. Berdasarkan perjalanan sejarah bangsa Indonesia, peran mahasiswa memiliki andil besar dari awal mula lahirnya bangsa indoesia sampai saat ini. Di mulai dengan perkumpulan mahasiswa kedokteran saat itu membentuk organisasi Budi Utomo karena keprihatinan mereka terhadap rakyat Indonesia yang saat itu mendapatkan sikap diskriminasi di tanahnya sendiri, sehingga mereka melalukan perlawanan dengan membentuk organisasi sebagai wadah mereka untuk mencapai tujuannya yakni merdeka. Selain itu setiap pergantian kekuasaan pasti selalu melibatkan peran mahasiswa, bagimana mereka terlibat dalam jatuhnya orde lama karena saat itu pemerintahan Sukarno gagal dalam menjalankan roda pemerintahan sebab perekonomian memburuk ditambah dengan adanya pristiwa gerakan 30 September yang didalangi oleh PKI. Lalu bagaimana mahasiswa terlibat ketika Suharto di masa orde baru dianggap gagal sebab di masa pemerintahannya praktik KKN semakin menggila sehingga lahirnya peristiwa reformasi 98 yang di inisiasi oleh mahasiswa. Melihat peran mahasiswa yang begitu pentingnya bagi negara tidaklah berlebihan mengatakan bahwa mahasiswa merupakan salah satu bagian dari sumber daya manusia yang penting bagi bangsa dan negar yang kelak akan menjadi generasi penerus dan cendekiawan muda dalam pembangunan bangsa. Di sisi lain, mahasiswa merupakan insan yang multi dimensi yakni sebagai bagian dari civitas akademik dan bagian dari generasi muda yang berperan aktif menentukan arah perkembangan bangsa Indonesia. Mahasiswa pada dasarnya merupakan garda terdepan sebagai harapan masyarakat dalam mewujudkan perubahan dimasyarakat ke arah yang lebih baik.

Namun, pada kenyataannya saat ini mahasiswa dihadapkan dengan berbagai permasalahan yang ada salah satunya adalah lunturnya karakter yang mencerminkan kepribadian bangsa. Yang artinya bisa jadi dimasa depan bangsa ini akan mengalami kesulitan mencari sosok pemimpin yang memiliki karakter bangsa. Penyebabnya karena hilangnya kemampuan berpikir kritis dan pemecahan masalah mahasiswa mulai meredup sejalan dengan menyerbaknya sifat hedonisme, individualisme, dan sikap pasif terhadap isuisu sosial dikalangan mahasiswa. Menurut Sunatra (2016, hlm. 129) hedonisme sebagai fenomena dan gaya hidup sudah tercermin dari perilaku generasi muda sehari-hari, mayoritas pelajar berlomba dan bermimpi untuk bias hidup mewah dan berfoya-foya. Hal ini didukung oleh pendapat Amir (2013, hlm. 54) hedonisme telah menghantam bangsa Indonesia sehingga hampir lupa dengan nilainilai kebudayaan lokal dan agama yang dianut. Diperkuat dengan penelitian yang dilakukan oleh Zulkifli (2016) bahwa 14 dari 16 orang mahasiswa menggunakan beasiswa untuk memenuhi gaya hidup hedonisnya. Di samping itu permasalahan ketahanan mentalitas mahasiswa dalam mengadapi masalah seperti kita lihat pada contoh kasus mahasiswa UMSU tusuk dosennya hingga tewas karena sering diusir dari kelas (Detik.com, Selasa 3 Mei 2016) lalu ada mahasiswa di Jakarta bunuh diri diduga karena skripsi ditolak dan putus cinta (Kompas, 27 Juli 2016). Selain itu Ditambah lagi dengan merebaknya budaya kekerasan di lingkungan mahasiswa, sebagaimana kasus di 
kampus Gunadarma Bekasi yang melibatkan 3 mahasiswa Gunadarma diduga membully mahasiswa berkebutuhan khusus (Kompas, 17 Juli 2017), dan juga Bentrok Mahasiswa FISIP dengan Teknik Universitas Riau saat Wisuda (Kompas, 6 Oktober 2017).

Fakta-fakta tersebut semakin memperkuat pentingnya pembentukan karakter kepemimpinan berlandasakan ideologi pancasila pada generasi muda khususnya mahasiswa sebagai leader of future. Sebab menurut Fakhriyah (2014) Seorang pemimpin ideal harus memiliki sifat kepemimpinan yang arif, bijaksana, dan demokratis. Hal ini menunjukan pentingnya pembentukan karakter kepemimpinan yang berlandaskan nilai-nilai pancasila diterapkan disetiap wadah pembinaan dan pengembangan diri. Seperti menyelenggarakan mata kuliah wajib Pendidikan Pancasila dalam mengembangkan jiwa kepemimpinan mahasiswa.

Apabila nilai-nilai Pancasila telah melekat menjadi karakter pemimpin tersebut, maka bukan tidak mungkin karakter tersebut akan menular dan diikuti oleh masyarakat, sehingga pada akhirnya kelak nilai-nilai Pancasila akan menjadi karakter dalam setiap kehidupan warga Negara Indonesia.

Berdasarkan latar belakang di atas, peneliti tertarik untuk melakukan penelitian dengan judul "Pembentukan Karakter Kepemimpinan Pancasila Di Politeknik Pelayaran Sorong (Suatu Telaah Pada Mata Kuliah Pendidikan Pancasila)" karena Generasi bangsa pada saat ini tantangan kehidupan berbangsa dan bernegara di kalangan generasi muda adalah gaya hidup bersifat hedonis dan individualistik, Dengan demikian pentingnya pembentukan karakter kepemimpinan yang berlandaskan nilai-nilai pancasila.

Dari uraian latar belakang penelitian di atas, dapat diidentifikasi masalah sebagai berikut: Melemahnya kualitas mahasiswa yang akan meneruskan tongkat kepemimpinan di masa depan. Menurunnya kemampuan berpikir kritis dan pemecahan masalah mahasiswa mulai meredup sejalan dengan menyerbaknya sifat hedonisme, individualisme, dan sikap pasif terhadap isu-isu sosial dikalangan mahasiswa. Hilangnya sosok pemimpin yang layak dijadikan panutan membuat mahasiswa kehilangan arah dan tujuan dalam menemukan jati dirinya. Pancasila yang merupakan jati diri bangsa telah mulai terlupakan dikalangan mahasiswa dan hanya hafal sila-sila Pancasila tanpa memaknai setiap sila yang terkandung di dalam Pancasila. Berdasarkan identifikasi masalah tersebut, maka dapat dirumuskan permasalahannya yaitu bagaimana relevansi mata kuliah Pendidikan Pancasila dalam membentuk karakter kepemimpinan Pancasila pada mahasiswa di Prodi Manajemen Transportasi Laut Politeknik Pelayaran Sorong.

\section{METODE}

Dalam penelitian ini penulis menerapkan metode penelitian kualitatif dengan pendekatan kepustakaan. Karena setidaknya ada beberapa alasan yang mendasarinya. Pertama bahwa sumber data tidak melulu bisa didapat dari lapangan. Adakalanya sumber data hanya bisa didapat dari perpustakaan atau dokumendokumen lain dalam bentuk tulisan, baik dari jurnal, buku maupun literatur yang lain. Menurut Mahmud (2011) dalam bukunya Metode Penelitian Pendidikan menjelaskan bahwa penelitian kepustakaan yaitu jenis penelitian yang dilakukan dengan membaca buku-buku atau majalah dan sumber data lainnya untuk menghimpun data dari berbagai literatur, baik perpustakaan maupun di tempattempat lain.

Studi kepustakaan diperlukan sebagai salah satu cara untuk memahami gejala- gejala baru yang terjadi yang belum dapat dipahami, kemudian dengan studi kepustakaan ini akan dapat dipahami gejala tersebut. Sehingga dalam mengatasi suatu gejala yang terjadi, penulis dapat merumuskan konsep untuk menyelasaikan suatu permasalahan yang 
muncul. Menurut Creswell (2015, hlm. 170) Tinjauan kepustakaan adalah rangkuman tertulis dari berbagai artikel jurnal, buku, dan dokumen-dokumen lain yang mendeskripsikan situasi informasi, jadi data pustaka tetap andal untuk menjawab persoalan penelitinya. Bagaimanapun, informasi atau data empirik yang telah dikumpulkan oleh orang lain, baik berupa buku-buku, laporan-laporan ilmiah ataupun laporan-laporan hasil penelitian tetap dapat digunakan oleh peneliti kepustakaan. Bahkan dalam kasus tertentu data lapangan masih kurang signifikan untuk menjawab pertanyaan penelitian yang akan dilaksanakan.

Penelitian ini merupakan jenis penelitian kepustakaan atau library research. Maka sumber data bersifat kepustakaan atau berasal dari berbagai literatur, di antaranya buku, jurnal, surat kabar, dokumen pribadi dan lain sebagainya. Untuk lebih jelasnya, maka sumber data dalam penelitian ini adalah sumber data pokok yang langsung dikumpulkan peneliti dari objek penelitian. Adapun sumber utama dalam penelitian ini adalah RPS dan buku ajar, yakni RPS Pendidikan Pancasila dan Buku Ajar Pendidikan Pancasila yang digunakan di Politeknik Pelayaran Sorong. Adapun alasan memilih RPS dan buku ajar Pendidikan Pancasila untuk melihat pembentukan karakter kepemimpinan Pancasila di Politeknik Pelayaran Sorong karena di dalam RPS dapat kita lihat arah pembelajaran mata kuliah ini dari mulai capaian pembelajaran, buku ajar, metode,dan pengalaman belajar mahasiswa dalam upaya bagaimana pembentukan karakter kepemimpinan Pancasila di perguruan tinggi melalui mata kuliah wajib pendidikan Pancasila.

Penulis menggunakan teknik pengumpulan data dengan cara dokumentasi karena jenis penelitian ini adalah penelitian kepustakaan. Penelitian kepustakaan adalah penelitian yang sumber data empirik yang primer maupun sekunder berasal dari buku- buku, dokumen-dokumen, jurnal, atau literatur-literatur yang lain.

Teknik dokumentasi digunakan untuk menggali dan mengumpulkan data dari sumber-sumber bacaan yang berkaitan dengan permasalahan dalam penelitian ini. Data primer atau sumber utama adalah berasal dari RPS dan buku ajar Pendidikan Pancasila di Politeknik Pelayaran Sorong. Kemudian untuk pengumpulan data penunjang atau pelengkap, diperoleh dengan menggali data dari buku-buku lain yang berhubungan dengan masalah penelitian.

\section{HASIL DAN PEMBAHASAN Kepemimpinan Pancasila}

Pada dasarnya kehidupan bangsa Indonesia memiliki nilai-nilai yang dijadikan norma dasar dan dasar negara Indonesia yakni Pancasila. Maka penggambaran karakter bangsa Indonesia secara inti adalah penjabaran dari nillai-nilai Pancasila. Secara nyata bahwa suatu konsepsi dan cita-cita dibutuhkan oleh semua bangsa jika ditinjau dari arus sejarah yang ada, akan sangat bahaya apabila suatu bangsa tidak memiliki konsep dan cita-cita (Sukarno, 2015). Sebab cita cita ideal merupakan pondasi dasar moralitas bagi setiap bangsa. Seperti Gardner (Latif, 2011) memiliki pandangan terkait pentingnya cita cita ideal bagi semua bangsa "no nation can achieve greatness unless it believes in something, and unless that something has moral dimensions to sustain a great civilization". Dalam mencapai sebuah kebesaran tidak ada bangsa yang dapat mencapainya terkecuali apabila bangsa tersebut meyakini terhadap sesuatu dan sesuatu yang diyakaini itu di dalamnya memiliki unsur-unsur moral agar dapat menyangga sebuah peradaban besar

Kepemimpinan Pancasila memiliki arti bahwa di dalam sebuah kepemimpinan haruslah berlandaskan pada nilai nilai dalam Pancasila. Artinya seorang pemimpin apapun jenis posisinya dan bidang mesti merujuk pada nilai-nilai Pancasila. Dengan berupaya menerapkan fungsi kepemimpinannya dengan 
berlandaskan nilai-nilai Pancasila maka seseorang memiliki jiwa Pancasila dalam kepemimpinannya. Nilai-nilai Pancasila yang ada dalam jiwa dan kepribadian pada seorang pemimpin pada akhirnya akan diinternalisasikan pada bawahannya. Nilainilai Pancasila dapat dijadikan tolak ukur warga negara dalam berprilaku sehari-hari. Direktorat pembelajaran dan kemahasiswaan (2013) membagi ke dalam tiga bagian mengenai implementasi nilai nilai Pancasila yang terdiri dari: nilai dasar, nilai instrumental, nilai praksis. Ketiga nilai tersebut dijadikan seperangkat moral dan etika bermasyarakat berbangsa dan bernegara oleh bangsa Indonesia.

Nilai dasar memiliki lima unsur sitem nilai yang sampai kapanpun tidak akan pernah berubah, yakni nilai Ketuhanan Yang Maha Esa, nilai Kemanusiaan yang adil dan beradab, nilai Persatuan Indonesia, nilai Kerakyatan yang dipimpin oleh hikmat kebijaksanaan dalam permusyawaratan/perwakilan, dan nilai Keadilan sosial bagi seluruh rakyat Indonesia. Sementara ilai instrumental adalah penjabaran dari nilai dasar, artinya bahwa seluruh perangkat perundang-undangan wajib berangkat dari penjabaran nilai-nilai dasar Pancasila yang kedudukannya terdapat dalam pembukaan dan batang tubuh Undang-undang Dasar 1945. Pihak-pihak yang memiliki tugas akan pelaksanaan penjabaran nilai dasar Pancasila menjadi nilai-nilai instrumental adalah mereka para penyusun peraturan perundang-undangan seperti yang terdapat di lembaga-lembaga legislatif, eksekutif, dan yudikatif dari tingkat pusat hingga daerah. Apabila semua warga negara dapat tunduk dan patuh asas pada nilai-nilai instrumental, hal ini dapat dikatakan bahwa sesungguhnya nilai praksis Pancasila telah menjadi wujud nyata pada jiwa dan kepribadian setiap warga negara.

Apabila merujuk pada nilai nilai Pancasila, maka seorang pemimpin Pancasila harus dapat mengaplikasikan nilai-nilai Pancasila pada tingkah lakunya. Nangga
(2015) mengartikan bahwa kepemimpinan Pancasila itu kepemimpinan yang mampu mengarah dan membawa masyarakat secara sadar dirinya seorang anggota masyarakat berbangsa dan bernegara yang memiliki pandangan hidup Pancasila dan berpedoman pada Undang-undang Dasar 1945. Maka dari itu kepemimpinan Pancasila yang berpedoman pada nilai-nilai Pancasila adalah barometer sosok pemimpin dalam bangsa Indonesia. Hal ini dijelaskan secara tegas Afandi (2013) yang berpendapat bahwa setiap bangsa harus mampu menentukan sendiri kriteria sosok pemimpinnya, agar bangsa tersebut mampu mengembangkan dan mencapai tujuannya secara berkelanjutan. Tolak ukur sosok pemimpin di Indonesia wajib berdasarkan pada peraturan perundang-undangan, dengan begitu munculnya sosok pemimpin akan sesuai dengan harapan masyarakat dalam menggapai cita-cita untuk diwujudkan bersama yakni masyarakat adil dan makmur,

Sebagai pandangan hidup bangsa Indonesia, nilai-nilai Pancasila sudah semestinya dijadikan parameter dalam pembentukan karakter pada seorang warga negara Indonesia tidak terkecuali menjadi tolak ukur pemimpin yang ideal. Untuk itu, menurut Nangga (2015) seorang pemimpin yang ideal diharapkan memenuhi kriteria: (1) seorang yang takwa kepada Tuhan Yang Maha Esa; (2) seorang yang menjunjung tinggi nilainilai kemanusiaan yang adil dan beradab; (3) seorang yang memiliki rasa persatuan Indonesia yang tinggi tanpa membedakan seseorang berdasarkan kepentingan tertentu; (4) seorang yang mampu mengembangkan semangat musyawarah/mufakat secara baik demi kepentingan bangsa dan negara; dan (5) seorang yang mampu mengembangkan pembangunan nasional untuk mencapai keadilan sosial bagi seluruh rakyat Indonesia.

Kepemimpinan Pancasila dapat menjadi contoh dalam menunjukan dan meyakinkan bahwa nilai-nilai Pancasila masih 
sangat relevan, yakni kepemimpinan yang benar-benar di percayai oleh masyarakat, sebab menurut Kariadi (2017) hanya kepemimpinan yang bersih, transparan, dan profesional yang bisa dipercaya masyarakat. Sehingga dengan demikian untuk mengembalikan Pancasila sebagai landasan hidup berbangsa dan bernegara, dibutuhkan kepemimpinan yang bersih, transparan, dan profesional. Maka urgensi nilai-nilai Pancasila menjadi landasan kehidupan berbangsa dan bernegara, untuk bisa menjadi instrumen menangkal krisis yang bersifat multidimensional. Dengan mengembalikan Pancasila sebagai landasan hidup maka dimulai dari cara bersikap dan berprilaku termasuk menjadi landasan dalam mengembangkan kriteria kepemimpinan yang ideal.

Pancasila seringkali dianggap sekedar wacana, nilai-nilanya tidak termanifestasikan secara nyata dalam kehidupan, dan tidak bisa jadi solusi bangsa. Pancasila sering dianggap sebagai bagian dari masalah, karena dianggap sebagai instrumen dari Orde Baru untuk memanipulasi dan menindas rakyat. Namun di sisi lain, rakyat sudah tidak percaya siapapun, terutama yang sudah berkuasa dan jadi pemimpin, karena mereka dianggap sudah gagal memenuhi janji proklamasi dan tidak perduli kepada rakyat. Ketika para pemimpin ini bicara soal Pancasila, rakyat semakin antipati terhadap Pancasila itu sendiri. Hanya dengan kepemimpinan yang betul-betul bersih, transparan, dan profesional, nilai-nilai luhur Pancasila bisa betul-betul menjadi landasan hidup yang nyata dan membawa kesejahteraan bagi bangsa dan negara. Azra (2008) menegaskan berbagai upaya perlu dilakukan guna mengembangkan relevansi Pancasila sebagai dasar wawasan kebangsaan dan identitas nasional Indonesia di tengah berbagai tantangan yang dihadapi negara-bangsa Indonesia.

\section{Mata Kuliah Pendidikan Pancasila dalam Membentuk Karakter Kepemimpinan Pancasila Pada Mahasiswa}

Lahirnya ketentuan Pasal 35 ayat (3)

Undang-undang Nomor 12 Tahun 2012 tentang Pendidikan Tinggi menyatakan bahwa kurikulum pendidikan tinggi wajib memuat mata kuliah Agama, Pancasila, Kewarganegaraan, dan Bahasa Indonesia. Hal ini menunjukkan bahwa negara menghendaki agar Pendidikan Pancasila dilaksanakan dan wajib dimuat dalam kurikulum perguruan tinggi sehingga mata kuliah Pendidkan Pancasila dapat lebih fokus dalam membina pemahaman dan penghayatan mahasiswa mengenai ideologi bangsa Indonesia. Ini berarti Pendidikan Pancasila diharapkan dapat menjadi ruh dalam membentuk karakter mahasiswa guna mengembangkan jiwa profesionalismenya sesuai dengan bidang studinya masing-masing. Hal tersebut, menjadi landasan utama mengapa penelitian ini mengkaji pembentukan karakter kepemimpinan melalui Pendidikan Pancasila.

Pentingnya karater Pancasila dalam sebuah kepemimpinan ideal karena pemimpin yang berkarakter memiliki daya tarik tersendiri. Ia tidak perlu menarik pengikut. Orang akan serta merta mengikutinya karena pemimpin yang berkarakter memiliki kestabilan yang menjadikannya pegangan bagi pengikutnya. Daya tarik di sini adalah ia memiliki ciri khas dalam memimpin sehingga akan menarik pengikutnya tersebut dengan setia memegang teguh nilai-nilai yang ditinggalkan hingga generasi-generasi berikutnya. Dengan begitu pentingnya pembentukan karakter kepemimpinan Pancasila sebagai upaya memelihara dan mewariskan nilai-nilai Pancasila hingga ke generasi-genarsi berikutnya. Upaya tersebut dapat dilakukan dengan berbagai cara salah satunya dengan cara menyelenggarakan mata kuliah wajib pendidikan pancasila di perguruan tinggi. 
Salah satu indikasi bahwa mata kuliah pendidikan Pancasila sebagai wahana pembentukan karakter kepemimpinan Pancasila terlihat dari dari Standar Kompetensi Lulusan (SKL) mahasiswa yang dirumuskan oleh Direktur Jenderal Perguruan Tinggi (Dikti) seperti pada Tabel 1 berikut ini.

Tabel 1. Standar Kompetensi Lulusan

\begin{tabular}{|c|c|}
\hline Domain & Standar Kompetensi Kelulusan \\
\hline 1. Sikap & $\begin{array}{lrr}\text { a. Memiliki perilaku yang } \\
\text { mencerminkan sikap orang dewasa } \\
\text { yang beriman, berakhlak mulia, } \\
\text { mandiri, kreatif, bertanggung } \\
\text { jawab, berbudaya dan berinteraksi } \\
\text { secara efektif dengan lingkungan } \\
\text { social serta alam. } \\
\text { b. Berkontribusi aktif dalam } \\
\text { kehidupan berbangsa dan } \\
\text { bernegara termasuk berperan } \\
\text { dalam pergaulan dunia dengan } \\
\text { menjunjung tinggi penegakan } \\
\text { hukum }\end{array}$ \\
\hline $\begin{array}{l}\text { 2.Penget } \\
\text { ahuan }\end{array}$ & $\begin{array}{l}\text { a. Memiliki pengetahuan prosedural } \\
\text { dan metakognitif dalam konsep } \\
\text { teoritis bidang pengetahuan } \\
\text { tertentu secara umum dan khusus } \\
\text { serta mendalam dengan wawasan } \\
\text { kebangsaan, kenegaraan dan } \\
\text { peradaban. } \\
\text { b. Terkait dengan fenomena dan } \\
\text { kejadian yang mencakup } \\
\text { penyebab, alternatif solusi, } \\
\text { kendala, dan solusi akhir. }\end{array}$ \\
\hline $\begin{array}{l}\text { 3.Ketera } \\
\text { mpilan }\end{array}$ & $\begin{array}{l}\text { a. Memiliki kemampuan pikir dan } \\
\text { tindak yang efektif dan inovatif } \\
\text { dalam ranah abstrak dan konkret } \\
\text { terkait dengan pengembangan diri } \\
\text { sesuai dengan bakat dan } \\
\text { kemampuannya. } \\
\text { b. Mampu memberikan petunjuk } \\
\text { dalam memilih alternatif solusi } \\
\text { secara mandiri dan/atau kelompok }\end{array}$ \\
\hline
\end{tabular}

Pendidikan Pancasila
SKL merupakan standar atau tolak ukur terhadap kemampuan atau kecakapan seseorang. Kompetensi yang diharapkan dari pendidikan Pancasila dapat dikelompokkan menjadi tiga macam. Pertama untuk memunculkan civic knowledge yaitu mengetahui Pancasila yang benar yang dapat dipertanggungjawabkan kebenarannya baik secara yuridis konstitusional maupun secara objektif ilmiah. Secara yuridis konstitusional maksudnya bahwa Pancasila adalah sebagai dasar negara guna mengatur penyelenggaraan pemerintahan negara. Oleh karena itu tidaklah setiap orang boleh memberikan pengertian dan tafsiran menurut pendapatnya sendiri-sendiri. Secara objektif ilmiah maksudnya adalah bahwa karena Pancasila itu merupakan salah satu paham filsafat (philosopical way of thinking) maka uraiannya harus logis jelas dan tepat serta dapat diterima oleh akal sehat. Kedua civic disposition yaitu setiap orang Indonesia dapat menerapkan nilai-nilai Pancasila dalam kehidupan sehari-hari yaitu dalam kehidupan bermasyarakat berbangsa dan bernegara. Ketiga civic skills yaitu kemampuan untuk menerapkan nilai-nilai Pancasila dalam membuat kebijakan publik seperti membuat undang-undang atau peraturan-peraturan oleh pejabat yang berwenang

Merujuk pada SKL di atas terlihat bahwa inti dari penyelenggaran pendidikan Pancasila di perguruan tinggi terpusat pada mahasiswa yang memiliki sikap religius, beretika, bertanggung jawab, dan memiliki keterampilan life skill yang baik dengan memiliki wawasan kebangsaan yang mumpuni. Sepintas SKL ini menunjukan bagaimana pembentukan karakter khususnya kepemimpinan dapat dibentuk melalui mata kuliah pendidikan Pancasila. Artinya sebagai pembelajaran tentang kepribadian, pendidikan Pancasila memiliki substansi menghasilkan manusia dewasa Indonesia yang memiliki life skill yang mumpuni yang berkarakter Pancasila. 
Dengan begitu, interpretasi membentukan karakter kepemimpinan Pancasila dalam mata kuliah pendidikan pancasila yakni mahasiswa mampu menumbuhkan sikap mental yang penuh tanggung jawab serta cerdas yang ditunjukkan dalam perilaku: 1) Beriman dan bertaqwa terhadap Tuhan Yang Maha Esa. 2) Berperikemanusiaan yang adil dan beradab. 3) Mendukung persatuan bangsa 4) Mendukung kerakyatan yang mengutamakan kepentingan bangsa dan negara di atas kepentingan perorangan. 5) Mendukung upaya untuk mewujudkan keadilan sosial. Artinya batasan karakter kepemimpinan Pancasila yang dimaksud dalam penelitian ini ialah seorang pemimpin yang menyelipkan nilai-nilai Pancasila seperti religius, beretika, dan bertanggung jawab dalam gaya kepemimpinannya, sehingga akan menarik pengikutnya yang setia memegang teguh nilainilai yang ditinggalkannya hingga generasigenerasi berikutnya

Petunjuk lain yang mengisyaratkan Pendidikan Pancasila sebagai sarana pembentukan karakter kepemimpinan Pancasila adalah dengan melihat isi dari komponen pembelajaran mata kuliah Pendidikan Pancasila seperti RPS yang meliputi capaian pembelajaran matakuliah, bahan ajar, metode, media, sumber, penilaian pembelajaran. Hasil temuan RPS Pendidikan Pancasila di Politeknik Pelayaran Sorong disusun secara mandiri oleh dosen, sebab dalam penyusunan RPS setidaknya harus mempertimbangkan tingkat partisipasi mahasiswa, penerapan teknologi informasi dan komunikasi, keterkaitan dan keterpaduan antar materi, umpan balik, dan tindak lanjut.

Salah satu indikator untuk mengetahui pendidikan Pancasila sebagai sarana pembentukan karakter kepemimpinan Pancasila melalui kajian capaian pembelajaran yang tercantum dalam RPS. Sebab capaian pembelajaran diartikan sebagai petunjuk arah dalam mencapai tujuan karena di dalamnya berisi suatu pernyataan tentang apa yang diharapkan diketahui, dipahami, dan dapat dikerjakan oleh mahasiswa setelah menyelesaikan suatu periode belajar. Dalam capaian pembelajaran pendidikan Pancasila yang diselenggarakan Politeknik Pelayaran Sorong setidaknya ada beberapa yang isinya berorientasi pada pembentukan karakter kepemimpinan Pancasila, seperti:

1. Bertakwa kepada Tuhan Yang Maha Esa dan mampu menunjukkan sikap religius;

2. Mampu menjunjung tinggi nilai kemanusiaan dalam menjalankan tugas berdasarkan agama, moral, dan etika;

3. Mampu berkontribusi dalam peningkatan mutu kehidupan bermasyarakat, berbangsa, bernegara, dan kemajuan peradaban berdasarkan Pancasila;

4. Mampu berperan sebagai warga negara yang bangga dan cinta tanah air, memiliki nasionalisme serta rasa tanggungjawab pada negara dan bangsa;

5. Mampu bertanggungjawab atas pencapaian hasil kerja kelompok dan melakukan supervisi dan evaluasi terhadap penyelesaian pekerjaan yang ditugaskan kepada pekerja yang berada di bawah tanggungjawabnya

6. Mampu memperoleh informasi dari data dan melakukan analisis data secara bertanggungjawab

Dari isi capaian pembelajaran pendidikan Pancasila di Politeknik Pelayaran Sorong cenderung menitikberatkan kepada sikap dan keterampilan mahasiswa. Yakni memiliki sifat religius, beretika, rasa cinta tanah air, mengutamakan kepentingan bersama, serta bertanggung jawab terhadap penyelesaian pekerjaan yang ditugaskan kepada pekerja yang berada di bawah tanggungjawabnya, hal ini sejalan dengan karakter kepemimpinan pancasila menurut Zulfikar \& Permady (2021) bahwa pemimpin yang memiliki karakter Pancasila adalah pemimpin yang memiliki sifat religius, bermoral, beretika, rasa cinta tanah air, 
mengutamakan kepentingan bersama, dan setiap keputusannya mengandung kebaikan untuk organisasi atau bidang yang dipimpinnya.

Untuk menunjang keberhasilan capaian pembelajaran di atas maka dibutuhkan bahan ajar yang mendukung tercapainya capian pembelajaran tersebut. Bahan ajar pada pembelajaran pendidikan pancasila di bagi ke dalam beberapa pokok bahasan, diantaranya:

1. Pancasila dalam kajian sejarah bangsa Indonesia

2. Pancasila sebagai Dasar Negara

3. Pancasila sebagai ideologi negara

4. Pancasila sebagai sistem filsafat

5. Pancasila sebagai sistem etika

6. HAM dalam prespektif pancasila

7. Pancasila sebagai paradigma pembangunan nasional

Terlihat dari pokok bahasan di atas, bahwa inti dari pembelajaran Pendidikan Pancasila menitikberatkan pada mahasiswa agar memiliki wawasan dan mampu menempatkan Pancasila sesuai dengan kedudukannya. Hal ini sejalan dengan pernyataan Zulfikar \& Permady (2021) bahwa Pancasila selayaknya hadir disetiap aktivitas manusia Indonesia, sebab Pancasila memiliki nilai kebenaran yang sumbernya digali dari sosial budaya masyarakat Indonesia. Urgensi pemahaman mengenai Pancasila dalam upaya pembentukan karakter kepemimpinan Pancasila agar pemahamannya mengenai pemimpin yang ideal tidak telepas dari nilainilai Pancasila. Sehingga hal itu akan membawanya sebagai karakter dalam gaya kepemimpinannya.

Agar bahan ajar ini dapat dipahami dan diimplementasikan oleh mahasiswa, maka dibutuhkan sebuah metode yang tepat dalam memberikan pengetahuan Pancasila pada mahasiswa. Dinjau dari RPS Pendidikan Pancasila Politeknik Sorong menggunakan model yang menekankan mahasiswa sebagai pusat dalam pembelajaran. setidaknya ada dua metode yang dianggap tepat dalam mentransmisikan pengetahuan Pancasila kepada mahasiswa yakni menggunakan metode small group discussion dan studi kasus di mana kedua metode ini memiliki kelebihan masing-masing yakni:

\section{Small Group Discussion}

Small Group Discussion merupakan salah satu metode pembelajaran aktif dimana dalam proses pembelajaran mahasiswa dibagi menjadi kelompok-kelompok kecil guna memecahkan dan mendiskusikan beberapa topik permasalahan. Topik yang didiskusikan berupa materi yang sesuai dengan standar kompetensi dan kompetensi dasar. Pembelajaran dengan strategi Small Group Discussion lebih mengutamakan pola kerjasama dalam kelompok kecil sehingga mahasiswa tidak ada yang merasa bahwa dirinya yang paling pintar dan menguasai materi (Saraswati, 2018). Dengan adanya strategi Small Group Discussion, diharapkan mahasiswa terbiasa untuk mengeluarkan pendapat dan bekerjasama dalam mengembangkan keterampilan sosial. Metode ini dipilih untuk memberikan pengalaman kepada mahasiswa untuk mentrasnformasikan nilai-nilai Pancasila dalam memimpin sebuah kelompok.

2. Studi Kasus

Metode studi kasus adalah suatu desain pembelajaran berbasis tingkat satuan pendidikan metode ini berbentuk penjelasan tentang masalah, kejadian atau situasi tertentu, kemudian mahasiswa ditugasi mencari alternatif pemecahannya kemudian metode ini dapat juga digunakan untuk mengembangkan berpikir kritis dan menemukan solusi baru dari sutu topik yang dipecahkan (Juliawati, 2017). Metode ini dipilih untuk melatih life skill mahasiswa yang penting dimiliki dalam kepemimpinan. Selain menujujung nilai-nilai Pancasila seorang pemimpin harus memiliki kemampuan yang dibutuhkan sebagai seorang pemimpin ideal salah satunya adalah memecahan masalah dengan mencari solusi dari suatu masalah yang dipecahkan 
Dari metode yang dipilih, terlihat bahwa dalam pembelajaran pendidikan Pancasila lebih menekankan pada bagaimana mahasiswa memiliki sikap dan keterampilan yang mumpuni dengan tidak menghilangkan nilai nilai Pancasila dari segala aktivitas kehidupannya.

Dari keseluruhan hasil kajian di atas, terlihat bahwa Pendidikan Pancasila sebagai sarana Pembentukan karakter kepemimpinan Pancasila mengacu pada Standar Kompetensi Lulusan menitikberatkan pada keseimbangan antara sikap, pengetahuan dan keterampilan, di mana ketiga itu dilandasi nilai-nilai Pancasila. Dari SKL tersebut dituangkan penjabaran secara rinci dalam RPS yang dibuat oleh dosen Politeknik Pelayaran Sorong dengan disesuaikan dengan kemampuan dan kondisi mahasiswa Politeknik Pelayaran Sorong. Di dalam RPS tersebut setidaknya terdapat capaian pembelajaran, bahan ajar, dan metode yang memusatkan pada pembentukan karakter kepemimpinan Pancasila

\section{KESIMPULAN}

Karakter kepemimpinan Pancasila yang dimaksud dalam penelitian ini ialah seorang pemimpin yang menyelipkan nilai-nilai Pancasila seperti religius, beretika, dan bertanggung jawab dalam gaya kepemimpinannya, sehingga akan menarik pengikutnya tersebut yang setia memegang teguh nilai-nilai yang ditinggalkannya hingga generasi-generasi berikutnya. Salah satu upaya menerapkan karakter kepemimpinan Pancasila di Politeknik Pelayaran Sorong adalah dengan menyelenggarakan mata kuliah Pendidikan Pancasila. Penerapan karakter kepemimpinan Pancasila pada mata kuliah pendidikan Pancasila diimplementasikan pada proses pembelajaran. hal ini terlihat dari komponen pembelajarannya yakni RPS. Dari pengembangan RPS pembentukan karakter kepemimpinan Pancasila terlihat dari capian pembelajaran yang menekankan mahasiswa memiliki sifat religius, beretika, serta mampu berperan sebagai warga negara yang bangga dan cinta tanah air, memiliki nasionalisme serta rasa tanggungjawab pada negara dan bangsa. Pemilihan materi yang tepat juga menjadi faktor utama dalam menerapkan karakter kepemimpinan Pancasila pada mata kuliah pendidikan Pancasila seperti Pancasila dalam kajian sejarah bangsa Indonesia, Pancasila sebagai Dasar Negara, Pancasila sebagai ideologi negara, Pancasila sebagai sistem filsafat, Pancasila sebagai sistem etika, HAM dalam prespektif pancasila, dan Pancasila sebagai paradigma pembangunan nasional.

Penggunaan metode dalam aktivitas pembelajaran memusatkan proses pembelajaran pada mahasiswa seperti small group discussion dan studi kasus. Kelebihan dari pendekatan ini adalah mahasiswa tidak hanya memperoleh pengetahuan semata, lebih dari itu ia dapat mengembangkan keterampilan kepemimpinan seperti komunikasi, inisiatif, bekerja dalam kelompok, berbagi informasi, dan penghargaan terhadap orang lain dengan tidak menghilangkan nilai-nilai Pancasila. Kelebihan inilah yang menjadi konten utama dari pengembangan karakter kepemimpinan Pancasila di Politeknik Pelayaran Sorong melalui mata kuliah Pendidikan Pancasila.

\section{DAFTAR PUSTAKA}

Affandi, Idrus. 2011. Pendidikan Politik. Bandung: Universitas Pendidikan Indonesia Creswell, Jhon. 2015. Riset Pendidikan. Yogyakarta: PUSTAKA PELAJAR

Mahmud. (2011). Metode Penelitian Pendidikan. Bandung: CV Pustaka Setia

Sunatra, (2016). Pendidikan Politik, Bandung: LEKKAS

Afandi, Rahman. (2013). Efektifitas Kepemimpinan Transformasional Pesantren Bagi Peningkatan Mutu Lembaga Pendidikan Islam. Jurnal Kependidikan, Vol. 1 No. 1 Nopember 2013

Amir, Syafruddin. (2013). Pancasila As Integration Philosophy of Education And National Character. USA: International Journal Of Scientific \& Technology Research Volume 2, Issue 1, January 2013

Fakhriyah, F. (2014). Penerapan Problem Based Learning Dalam Upaya Mengembangkan Kemampuan Berpikir 
Kritis Mahasiswa. Jurnal Pendidikan IPA Indonesia. Vol 3, No 1 (2014). 95-101

Juliawati, Dosi. (2017). Studi Kasus Terhadap Mahasiswa Yang Menikah Saat Menempuh Masa Kuliah. Volume 13 no 2

Latif, Yudi. (2011). Revitalisasi Pancasila di Tengah Dua Fundamentalisme. Jakarta: Journal dignitas Volume VII No. 2 Tahun 2011

Nangga, Kamriah \& Mustari. (2015). Implementasi Kepemimpinan Pancasila Oleh Kepala Sekolah Di Smp Hang Tuah Makassar. Jurnal Universitas Negeri Makassar Volume II, Nomor 3, Desember 2015

Saraswati. (2018). Implementasi Metode Pembelajaran Small Group Discussion Untuk Meningkatkan Aktivitas Belajar Pada Kompetensi Dasar Jurnal Penyesuaian Siswa Kelas X Akuntansi Smk Muhammadiyah Kretek Tahun Ajaran 2017/2018. Volume 16 nomor 22018

Zulkifli, AR. (2016). Gaya Hidup Hedonisme Di Kalangan Mahasiswa Penerima Beasiswa Kaltim Cemerlang 2014 Di Fakultas Ilmu Sosial Dan Ilmu Politik Universitas Mulawarman. eJournal Sosiatri-Sosiologi. Volume 4, Nomor 1, 2016: $72-85$

Zulfikar, G \& Permady GC. (2021). Citra Wawasan Kebangsaan Generasi Muda: suatu kajian terhadap sikap anti radikalisme. Volume 7, Nomor 2, 2021

Zulfikar, G \& Permady, GC. (2021). Pembentukan Karakter Kepemimpinan Melalui Social Movement Pada Organisasi Kemahasiswaan. Volume 11, nomor 1, 2021

Undang-Undang Republik Indonesia Nomor 12 tahun 2012 Tentang Pendidikan Tinggi

Undang-Undang Republik Indonesia Nomor 20 Tahun 2013 Tentang Sistem Pendidikan Nasional

Cnbcindonesia (22 September 2021) dapat diakses melalui situs https://www.cnbcindonesia.com/news/2020 1216142816-4-209558/duh-indekspembangunan-manusia-ri-no-107-dari-189negara/2

Okezone (22 September 2021) dapat diakses melalui situs https://news.okezone.com/read/2021/09/01/ 519/2464606/depresi-gara-gara-skripsimahasiswa-ini-mau-bunuh-diri

Detik.com (22 September 2021 ) dapat diakses melalui situs https://news.detik.com/berita/d3202890/mahasiswa-umsu-tusuk-dosennyahingga-tewas-karena-sering-diusir-darikelas (13

Kompas (22 September 2021 ) dapat diakses melalui situs (13http://megapolitan.kompas.com/read/20 16/07/27/18015261/mahasiswa.bunuh.diri.d iduga.karena.skripsi.ditolak.dan.putus.cinta $(13$

Kompas (22 September 2021 ) dapat diakses melalui situs http://tv.kompas.com/read/2017/07/17/31b0 15003009039f29e673/3.mahasiswa.diduga. bully.mahasiswa.berkebutuhan.khusus

Kompas (22 September 2021 ) dapat diakses melalui situs http://regional.kompas.com/read/2017/10/0 6/06571711/bentrok-mahasiswa-fisipdengan-teknik-saat-wisuda-delapan-luka 